\title{
Advancement of the Acetylene Inhibition Technique Using Time Series Analysis on Air-Dried Floodplain Soils to Quantify Denitrification Potential
}

\author{
Ute Susanne Kaden ${ }^{1} * \mathbb{C}^{\circ}$, Elmar Fuchs ${ }^{2}$, Christian Hecht ${ }^{1}$, Thomas Hein ${ }^{3,4} \oplus^{\circ}$, Holger Rupp ${ }^{5}$, \\ Mathias Scholz ${ }^{1}$ (D) and Christiane Schulz-Zunkel ${ }^{1}$ \\ 1 UFZ-Helmholtz Centre for Environmental Research, Department of Conservation Biology, \\ Permoserstraße 15, 04318 Leipzig, Germany; christian.hecht@ufz.de (C.H.); mathias.scholz@ufz.de (M.S.); \\ christiane.schulz@ufz.de (C.S.-Z.) \\ 2 BfG—German Federal Institute of Hydrology, Am Mainzer Tor 1, 56068 Koblenz, Germany; fuchs@bafg.de \\ 3 BOKU-University of Natural Resources and Life Sciences, Gregor-Mendel-Straße 33, 1180 Vienna, Austria; \\ thomas.hein@boku.ac.at \\ 4 WasserCluster Lunz, Dr. Carl Kupelwieser Promenade 5, 3293 Lunz am See, Austria \\ 5 Helmholtz Centre for Environmental Research, Department of Soil System Sciences, \\ Falkenberg 55, 39615 Altmärkische Wische, Germany; holger.rupp@ufz.de \\ * Correspondence: ute-susanne.kaden@ufz.de
}

Received: 15 July 2020; Accepted: 26 October 2020; Published: 29 October 2020

\begin{abstract}
Denitrification in floodplain soils is one key process that determines the buffering capacity of riparian zones in terms of diffuse nitrate pollution. One widely used approach to measure the denitrification potential is the acetylene inhibition technique that requires fresh soil samples. We conducted experiments with air-dried soils using a time series analysis to determine the optimal rewetting period. Thus, air-dried soil samples from six different floodplain areas in Germany were rewetted for 1 to 13days to $100 \%$ water-filled pore space. We analyzed nitrogen accumulated as $\mathrm{N}_{2} \mathrm{O}$ in the top of anaerobic flasks with and without acetylene by gas chromatography after four hours of incubation. We observed an overall optimal rewetting of at least seven days for complete denitrification. We also saw the strong influence of $\mathrm{pH}$ and field capacity on the denitrification product ratio; in soils with $\mathrm{pH}<7$, we hardly assumed complete denitrification, whereas the treatments with $\mathrm{pH}>7$ achieved stable values after seven days of rewetting. This advanced method provides the opportunity to carry out campaigns with large soil sample sizes on the landscape scale, as samples can be stored dry until measurements are taken.
\end{abstract}

Keywords: denitrification potential; acetylene inhibition technique; rewetting; floodplain soils; riparian zone; ecosystem services; nitrate pollution; $\mathrm{N}_{2} \mathrm{O} ; \mathrm{N}_{2}$

\section{Introduction}

Floodplains that link the aquatic and terrestrial environment range from low-water to high-water levels and are characterized by floods and changing groundwater levels [1]. They make a significant contribution to the biodiversity of landscapes and also serve as important nutrient traps [2]. Denitrification - a microbial process where nitrate is permanently removed to the atmosphere as $\mathrm{N}_{2}$ helps to reduce the effects of mineralized nitrogen pollution [3,4]. It has long been considered as the most important process of removing nitrate permanently from soils. Newer studies show that dissimilatory nitrate reduction to ammonium (DNRA) also makes an important contribution to nitrogen removal, although the relationship between the two processes in floodplains remains partially unclear [5-7]. Further it is possible that ammonium produced via DNRA pathways is 
reconverted to nitrate via nitrification or even assimilated into biomass [8]. However, the aim of this study is not to quantify all these different pathways but rather assessing the dominant process in floodplain systems. This is why focusing on denitrification in this context is nevertheless useful. Due to changes in the frequency and duration of floods and the pulsing water level, the water regime controls aerobic and anaerobic soil conditions and consequently microbial processes [9]. It is known that extensive drying and rewetting stimulates denitrification loss, which means that management leading to fewer fluctuations in soil water content, could ultimately result in reduced denitrification [10]. However, in the case of an incomplete reaction, nitrous oxide $\left(\mathrm{N}_{2} \mathrm{O}\right)$, a highly efficient greenhouse gas, is emitted [11]. Various methods are used to measure denitrification, $\mathrm{N}_{2} \mathrm{O}$, and $\mathrm{N}_{2}$ emissions in terrestrial and aquatic environments. Three of the most commonly used methods are denitrification enzyme activity (DEA) measurements through the acetylene-based inhibition of $\mathrm{N}_{2} \mathrm{O}$ reduction with gas chromatography [12]; several methods use ${ }^{15} \mathrm{~N}$ determined by isotope-ratio mass spectrometry [13] and the direct quantification of denitrification by measuring $\mathrm{N}_{2}$ in flow or tight systems [14]. We recommend reading the reviews by Groffman et al. (2006) [15] and Saggar et al. (2013) [16], who presented the available methods for measuring and calculating denitrification, pointing out advantages but also potential problems and limitations in detail. In order to choose the appropriate method, it is important to consider it in the context of its targeted message and its scale and scope. The acetylene inhibition technique (AIT) has numerous limitations leading to bias that has not yet been sufficiently quantified [17-20]. Several reasons, e.g., the incomplete diffusion of acetylene in soil [17] or acetylene consumption by soil microorganisms [21] may be responsible for the incomplete inhibition of $\mathrm{N}_{2} \mathrm{O}$ reduction as recently shown by Yu et al., 2010 [22], Qin et al., 2012 [18], and Yuan et al., 2019 [20]. In addition, an inhibition of nitrification, leading to the suppression of $\mathrm{NO}_{3}$ supply [23,24] is receivable. Due to these limitations, an underestimation of actual soil denitrification potential (SDP) is likely $[18,25,26]$. Despite the possibility of overestimation, ${ }^{15} \mathrm{~N}$ tracer methods with more reliable estimates of denitrification are considered to be more appropriate [16]. However, only the procedures for the direct determination of $\mathrm{N}_{2}$ have the potential to quantify uncertainties in SDP based on AIT and should be used for correction $[18,26]$. Moreover, this direct method does not require the addition of an inhibitor or substrate (labeled or otherwise), i.e., no interference is expected with microbial soil processes [16]. However, it does require a complex incubation system and expensive instruments, as well as the ${ }^{15} \mathrm{~N}$ tracer techniques, which are not affordable for everyone.

After careful consideration of our objectives in this study, we opted for the technique AIT. These parameters of AIT that are considered to be particularly critical, such as aerobic atmosphere [20], low acetylene concentrations [27], incomplete acetylene diffusion [17,28], and acetylene consumption [29,30] can be adjusted in such a way that underestimation and bias are probably present, but as low as possible: Our experiments were conducted in an anaerobic atmosphere, with 10 vol\% acetylene, in shaken soil slurries to minimize diffusion effects and to experience a relatively short-time acetylene exposure to minimize consumption effects. It is also known that bias of AIT-derived SDP is higher in soils with low nutrient content and organic matter [19]. However, due to its simplicity and affordability, it has been proven very useful for comparing soils, ecosystems, and treatments $[15,17,31,32]$, enabling SDP to be estimated at the landscape level. It needs to be mentioned here, that denitrification potentials derived from this method are not suitable for determining actual nitrate removing capacity [12,27]. Moreover, also other nitrate removing processes are not covered in this study. With the main goal to provide data respectively tendencies about N-removal in floodplains the focus of the denitrification as one major process responsible for it, is suitable at this stage since other approaches for quantifying this process at the landscape level are not available.

The common assay for measuring the DEA with the AIT developed by Smith and Tiedje (1979) [33] and modified by Groffman et al. (1999) [12], uses soil slurries in an anaerobic environment under non-limiting carbon and nitrate concentrations and is related to the denitrifier population in soils, reflecting the long-term variations of denitrification-controlling factors [34]. This method requires 
"fresh" soil samples and many publications have described the use of this method [11,27,35-38] although many studies were conducted using rewetted "dried" soil samples [10,18,39,40].

Since drying and rewetting exert stress on the bacterial community [41], triggering biochemical processes that lead to pulsing $\mathrm{N}_{2} \mathrm{O}$ emissions [42], it seems obvious that experiments with dried soils will influence soil processes such as denitrification [10]. For the comparison and categorization of AIT-derived SDP, it is therefore important to find a standardized procedure that generates stable $\mathrm{N}_{2} \mathrm{O}$ values, even for air-dried soils. Preliminary experiments with 24-hour rewetting led us to select a broad and representative set of soil samples for our methodological DEA experiment, in terms of potential SDP. Factors affecting denitrification are divided into proximal and distal regulators: Proximal regulators directly affect the denitrifying community, leading to immediate changes in denitrification rates, while distal factors control the composition of these communities over larger spatial and temporal scales [16]. We opted for a selection based on the distal regulators field capacity (FC) and $\mathrm{pH}$ and the proximal regulator mineral nitrogen ( $\mathrm{Nmin}$ ) and applied different rewetting periods to $100 \%$ water-filled pore space (WFPS).

We aimed to further develop the AIT for DEA measurements with air-dried soils. In terms of the possible effects of drying and rewetting on the denitrification process, the main objectives were (i) to investigate the influence of different periods of rewetting for air-dried soils and (ii) to assess the influence of different soil characteristics that are known to strongly influence physicochemical properties in soils.

The advanced method offers comparable stable DEA results and the opportunity to carry out campaigns with large soil sample sizes on the landscape level, as samples can be stored dry until measurements are taken. Moreover, it enables the provision of data about denitrification as an ecosystem function in different floodplain areas. The delivery of such information is a key goal for the management of riparian zones [43]. With the help of AIT, we also obtain important information for improving the existing proxy-based approach for the quantification of $\mathrm{N}$-retention through denitrification in the floodplains of Germany.

\section{Materials and Methods}

\subsection{Field Sampling}

During July and September 2017, 113 soil samples from 6 different study areas in 4 different floodplains along German rivers (the Rhine, the Main, the Weser, and the Elbe) were collected. Sampling points were selected in the study areas according to a randomized design. For each sampling plot $(2 \times 2 \mathrm{~m})$, five repetitions $(10 \mathrm{~cm}$ diameter $\times 20 \mathrm{~cm}$ depth) were carried out using a soil auger. The soil samples that were collected were combined into one mixed sample for further analysis. One part was stored at $4{ }^{\circ} \mathrm{C}$ until the soil physical and chemical parameters were measured, whereas the other was air-dried and sieved $(2 \mathrm{~mm})$ and stored at room temperature until the DEA measurements were taken. We also characterized the soil types of all plots with a $3 \mathrm{~cm}$ diameter and at a depth of $100 \mathrm{~cm}$ and the soil density using three repetitions of soil cutter cores $\left(100 \mathrm{~cm}^{3}\right)$.

\subsection{Measurements of Soil Physical and Chemical Parameters}

The $\mathrm{pH}$ was measured with a glass electrode in a suspension of soil and water with a volume ratio of 1:5 [44]. The measurement of Nmin (the sum of nitrate and ammonium) was conducted by extracting ammonium and nitrate with a 0.0125 molar calcium chloride solution (ratio $1+4(\mathrm{~m}+\mathrm{V})$ ) and subsequent summation [45]. The particle size distribution of the soil material was determined by sieving and sedimentation [46]. Soil types were defined based on the amount of the fractions of clay, silt, and sand [47]. To calculate the FC from the soil type, soil bulk density and humus content (or total organic carbon (TOC)) were recorded. The soil bulk density was measured by drying and weighing $100 \mathrm{~cm}^{3}$ samples at $105^{\circ} \mathrm{C}$ until a constant weight [48]. TOC was measured by using a suspension 
method with 0.22 molar hydrogen chloride (ratio $1: 1(\mathrm{~m}: \mathrm{V})$ ) [49] and by subsequently multiplying by 1.7 to obtain the humus content [47].

\subsection{Measurements of Potential Denitrification Rates and $\mathrm{Net}_{2} \mathrm{O}$ Emission Rates}

We slightly modified the AIT standard procedure by Smith and Tiedje (1979) [33] that was modified by Groffman et al. (1999) [12] to determine the soil denitrification potential.

\subsubsection{Preincubation}

Soil samples were pre-incubated resp. rewetted for 1 day (d), 2d, $3 d, 4 d, 5 d, 6 d, 7 d, 9 d$, and $13 d$ to $100 \%$ WFPS and stored at $21{ }^{\circ} \mathrm{C}$ in the dark.

\subsubsection{Experiment}

From the available 113 soil samples, 12 were selected by using 3 parameters that are known to be the most decisive for the development of the denitrifying bacterial community: $\mathrm{pH}, \mathrm{Nmin}$, and FC. For each soil sample and each pre-incubation period, six $130 \mathrm{~mL}$ flasks were filled with 5 to $8 \mathrm{~g}$ of rewetted soil ( $5 \mathrm{~g}$ equivalent of dry soil). For 0 days of rewetting, dry soil was added, after which $5 \mathrm{~mL}$ of nutrient solution (final concentrations: $6.8 \mathrm{~g} / \mathrm{L} \mathrm{C}_{2} \mathrm{H}_{3} \mathrm{NaO}_{2}$ and $2.9 \mathrm{~g} / \mathrm{L} \mathrm{KNO}_{3}$ equal to $2 \mathrm{mg} \mathrm{C}^{-1}$ dry soil and $0.4 \mathrm{mg} \mathrm{N} \mathrm{g}^{-1}$ dry soil) were added. By adding $\mathrm{NO}_{3}-\mathrm{N}$ and soluble $\mathrm{C}$ any temporal changes were eliminated due to differences in sampling time [50] and an upper-bound estimate of in situ denitrification potential was provided [27]. The flasks were sealed with caps (air-tight from butyl rubber septa) that have two hoses with one valve each, followed by 3 minutes of flushing with $\mathrm{N}_{2}$ while shaking the flask gently to induce anaerobic conditions. Subsequently, in three of the six bottles, $13 \mathrm{~mL}(10 \mathrm{vol} \%)$ of $\mathrm{N}_{2}$ was removed and replaced by acetylene $\left(\mathrm{C}_{2} \mathrm{H}_{2}\right)$ using a syringe. Without the addition of acetylene, it was possible to transform $\mathrm{N}_{2} \mathrm{O}$ into $\mathrm{N}_{2}$, enabling the net $\mathrm{N}_{2} \mathrm{O}$ emission rate to be determined, as the presence of acetylene would inhibit the reduction of $\mathrm{N}_{2} \mathrm{O}$ to $\mathrm{N}_{2}$ [51]. After four hours of incubation in the dark at $21^{\circ} \mathrm{C}$, gas samples $(20 \mathrm{~mL})$ were taken and transferred into empty vials with butyl septa and crimped caps and stored upside down in water until measurements were taken. Due to this short incubation period, we decided on a one-time rather than hourly sampling, supported by several studies which analyzed a linear increasing $\mathrm{N}_{2} \mathrm{O}$ production over periods of up to 8 hours (e.g., [12,18-20,33,39]).

\subsubsection{Gas Chromatography}

Nitrogen that accumulated as $\mathrm{N}_{2} \mathrm{O}$ in the top of all flasks was analyzed by gas chromatography (GC-14B, Shimadzu, Duisburg, Germany) connected to an automatic sample-injection system (APS 96/20-K, ESWE, Gera, Germany). The gas chromatograph was equipped with an electron capture detector and a packed column (1/8" Hayesep-Q, 80/100 mesh, length 4m; Sigma-Aldrich, Darmstadt, Germany). For the $\mathrm{N}_{2} \mathrm{O}$ emission rates, the final $\mathrm{N}_{2} \mathrm{O}$ concentrations (ppm) were corrected for $\mathrm{N}_{2} \mathrm{O}$ dissolved in water (Bunsen coefficient $=0.65\left(21^{\circ} \mathrm{C}\right)$ ), divided by the incubation time $(4 \mathrm{~h})$ and expressed on the basis of dry soil matter $\left(\mathrm{ng} \mathrm{N} \mathrm{g}^{-1} \mathrm{~h}^{-1}\right)$. The potential denitrification rates were calculated as the difference between the net $\mathrm{N}_{2} \mathrm{O}$ emission rates in the two different treatments (with and without acetylene).

\section{Results}

\subsection{Selection of Soil Samples for the Time Series Analysis}

From all of the 113 samples $\mathrm{pH}$ varied between 5.92 and 9.04, whereas Nmin ranged from $0.21 \mathrm{mg} / 100 \mathrm{~g}$ dry matter (DM) to $6.72 \mathrm{mg} / 100 \mathrm{~g}$ DM with a median of $1.72 \mathrm{mg} / 100 \mathrm{~g}$ DM. Both were divided into two classes: $\mathrm{pH}$ below and above 7; Nmin below and above 1.72. The subset of the 12 soil samples ranged from a $\mathrm{pH}$ of 5.15 to 8.66 , whereas Nmin ranged from $0.21 \mathrm{mg} / 100 \mathrm{~g}$ DM to $3.02 \mathrm{mg} / 100 \mathrm{~g}$ DM. Field capacity varied from $20 \mathrm{vol} \%$ to $60 \mathrm{vol} \%$ and was subdivided into three classes 
on the basis of set threshold values of $39 \mathrm{vol} \%$ and $48 \mathrm{vol} \%$. As a result, we created a matrix of the 12 selected soil samples based on the 12 possible combinations of these 3 parameters (see Table 1). None of the 113 samples fit into group 11, which is why we investigated two samples from group 12, which was the most highly represented group.

Table 1. Selection of soil sample subset based on the combination of the defined classes and on the parameters: $\mathrm{pH}$, mineral nitrogen (Nmin), field capacity (FC) $(\mathrm{pH}$ value into 2 classes: low $(\mathrm{pH}<7)$ and high ( $\mathrm{pH}>7$ ); Nmin into 2 classes: low (Nmin < 1mg/100g DM) and high (Nmin > 1mg/100g DM); FC into 3 classes: class I-very low/low/medium (FC $=21$ vol $\%<$ FC $\leq 39$ vol $\%$ ), class II-high (FC $=39 \mathrm{vol} \%<\mathrm{FC}<48 \mathrm{vol} \%$ ), class III-very high (FC $>48 \mathrm{vol} \%$ ). Since there was no soil sample in the subset corresponding to combination 10 , two soils from combination 11 were analyzed.

\begin{tabular}{|c|c|c|c|c|c|c|c|c|c|}
\hline \multirow{2}{*}{$\begin{array}{c}\text { Combination } \\
\#\end{array}$} & \multirow[t]{2}{*}{ Group } & \multirow[t]{2}{*}{$\begin{array}{l}\text { Symbol } \\
\text { (Figure 1) }\end{array}$} & \multicolumn{2}{|c|}{ pH Value } & \multicolumn{2}{|c|}{$\begin{array}{c}\text { Mineral Nitrogen } \\
\text { Content } \mathrm{mg} / 100 \mathrm{~g} \mathrm{DM}\end{array}$} & \multicolumn{2}{|c|}{$\begin{array}{l}\text { Field Capacity } \\
\text { vol } \%\end{array}$} & \multirow[t]{2}{*}{ River } \\
\hline & & & Class & Value & Class & Value & Class & Value & \\
\hline 2 & \multirow[t]{2}{*}{ I } & $\bullet$ & $\begin{array}{l}10 \mathrm{~W} \\
(\mathrm{n} H<7)\end{array}$ & 5.93 & \multirow{2}{*}{$\begin{array}{c}\text { low } \\
(\mathrm{Nmin}<1)\end{array}$} & 0.451 & II & 43 & Elbe \\
\hline 3 & & $\Delta$ & & 5.50 & & 0.342 & III & 57 & Elbe \\
\hline 6 & II & $\Delta$ & $\begin{array}{c}\text { Low } \\
(\mathrm{pH}<7)\end{array}$ & 5.86 & $\begin{array}{c}\text { high } \\
(\mathrm{Nmin}>1)\end{array}$ & 1.870 & III & 57 & Elbe \\
\hline 7 & \multirow{3}{*}{ III } & - & \multirow{3}{*}{$\begin{array}{l}\text { high } \\
(\mathrm{pH}>7)\end{array}$} & 8.66 & \multirow{3}{*}{$\begin{array}{c}\text { low } \\
(\mathrm{Nmin}<1)\end{array}$} & 0.693 & I & 20 & Rhein \\
\hline 8 & & $\bullet$ & & 8.25 & & 0.556 & II & 43 & Rhein \\
\hline 9 & & $\Delta$ & & 8.30 & & 0.648 & III & 51 & Rhein \\
\hline 12.2 & IV & $\triangle$ & $\begin{array}{c}\text { high } \\
(\mathrm{pH}>7)\end{array}$ & 7.95 & $\begin{array}{c}\text { high } \\
(\mathrm{Nmin}>1)\end{array}$ & 2.636 & III & 57 & Rhein \\
\hline
\end{tabular}

\subsection{Time Series Analysis_-The Effects of Rewetting on DEA ( $\mathrm{N}_{2} \mathrm{O}$ Emissions in Treatments with Acetylene)}

$\mathrm{N}_{2} \mathrm{O}$ emission rates in treatments with acetylene (DEA) from soils rewetted directly before incubation ( 0 days of rewetting) were generally very low, with a mean net $\mathrm{N}_{2} \mathrm{O}$ flux rate ranging from 1 to $32 \mathrm{ng} \mathrm{N}_{2} \mathrm{O}-\mathrm{N} \mathrm{g}^{-1} \mathrm{~h}^{-1}$ in the groups I and II compared to 0-99 $\mathrm{ng} \mathrm{N}_{2} \mathrm{O}-\mathrm{N} \mathrm{g}^{-1} \mathrm{~h}^{-1}$ in the high $\mathrm{pH}$ class (groups III and IV). With rewetting we measured increasing $\mathrm{N}_{2} \mathrm{O}$ rates in the soils of all groups, but with differently shaped curves over time. In group I and II $\mathrm{N}_{2} \mathrm{O}$ emissions continued to rise over the rewetting period in some cases (e.g., \#1 and \#2), whereas in others they decreased after an initial increase (\#3) and in others, we hardly found any $\mathrm{N}_{2} \mathrm{O}$ emissions over the entire rewetting period (e.g., \#4: mean $\mathrm{N}_{2} \mathrm{O}$ emission rate $1.6 \pm 0.9 \mathrm{ng} \mathrm{N}_{2} \mathrm{O}-\mathrm{N} \mathrm{g}^{-1} \mathrm{~h}^{-1}$ ). In general, we measured the highest $\mathrm{N}_{2} \mathrm{O}$ emission rates of up to $304 \mathrm{ng} \mathrm{N}_{2} \mathrm{O}-\mathrm{N} \mathrm{g}^{-1} \mathrm{~h}^{-1}$ in those soils with $\mathrm{pH}<7$, with the highest Nmin and the highest FC (\#6).

In group III $\mathrm{N}_{2} \mathrm{O}$ emissions were of a similar magnitude to those in groups I and II, but more stable over time.

The three soils from group IV showed obvious peaks after $1 \mathrm{~d}$ of rewetting, which were more than three times greater than the highest $\mathrm{N}_{2} \mathrm{O}$ emission rates in all other groups (up to $1584 \mathrm{ng} \mathrm{N} \mathrm{O}_{2}-\mathrm{N} \mathrm{g}^{-1} \mathrm{~h}^{-1}$ ), resulting, after a major drop, in stable rates ranging from 701 to $722 \mathrm{ng} \mathrm{N}_{2} \mathrm{O}-\mathrm{N} \mathrm{g}^{-1} \mathrm{~h}^{-1}$ ).

The effects of different periods of rewetting (preincubation) on the emissions of $\mathrm{N}_{2} \mathrm{O}$ from the differently treated soils and on the denitrification product ratios calculated from these are shown in Figure 1.

3.3. Time Series Analysis-The Effects of Rewetting on $\mathrm{N}_{2} \mathrm{O}$ Emissions in Comparison Between Treatments with and without Acetylene-Denitrification Product Ratio $\mathrm{N}_{2} \mathrm{O} /\left(\mathrm{N}_{2}+\mathrm{N}_{2} \mathrm{O}\right)$

All soils from the groups I and II showed the same trend: curve progressions with acetylene followed the curves without acetylene, resulting in ratios fluctuating around one (Figure 1). 
In contrast, the soils in group III showed relatively constant ratios below one after day 1 . The stable mean ratios between rewetting on day 1 and day 13 range from $0.85 \pm 0.05(\# 8)$ over $0.48 \pm 0.08$ (\#9) to $0.30 \pm 0.08$ (\#7).

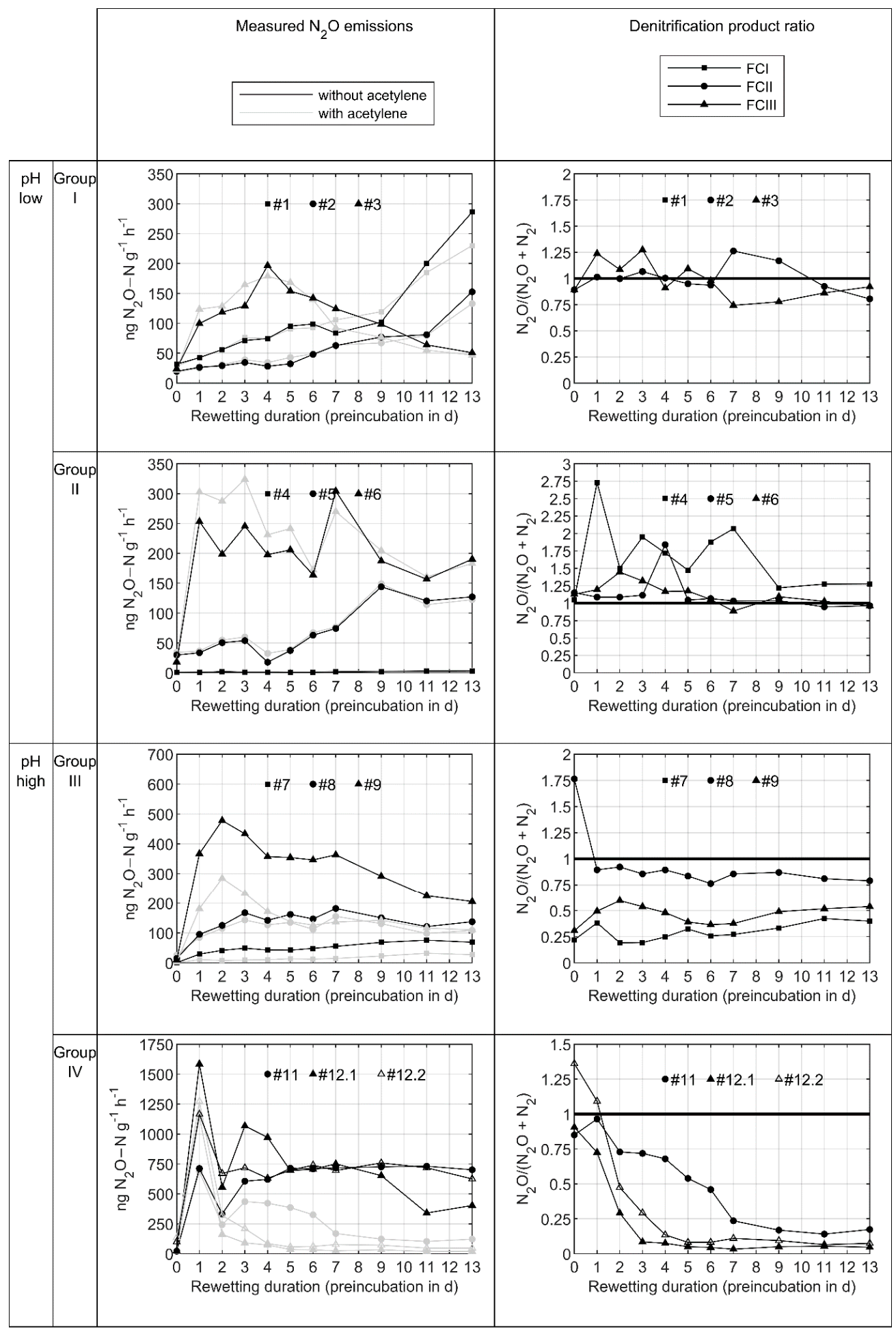

Figure 1. Measured $\mathrm{N}_{2} \mathrm{O}$ emissions in treatments with and without acetylene (left) and the denitrification product ratio $\left(\mathrm{N}_{2} \mathrm{O} /\left(\mathrm{N}_{2} \mathrm{O}+\mathrm{N}_{2}\right)\right)$ calculated from them (right). For a detailed legend see Table 1 . 
The three soil groups from group IV also showed stable mean ratios after different durations of preincubation ranging from $0.18 \pm 0.04$ (rewetting day 7 to day 13 , \#11) over $0.09 \pm 0.02$ (rewetting day 4 to day $13, \# 12.2$ ) to $0.05 \pm 0.02$ (rewetting day 3 to day $13, \# 12.1$ ).

Figure 2 shows that the median of the $\mathrm{N}_{2} \mathrm{O} /\left(\mathrm{N}_{2}+\mathrm{N}_{2} \mathrm{O}\right)$-ratio for the entire subset varies between 0.99 (day 1) and 0.80 (day 7) with no clear trend. When we only considered the median of the $\mathrm{N}_{2} \mathrm{O} /\left(\mathrm{N}_{2}+\mathrm{N}_{2} \mathrm{O}\right)$-ratio of the soil samples from groups III and IV we observed a clear decrease in rates with an increasing rewetting period (up to day $7=$ minimum of 0.25 ), and further on constant medians up to day 13 (day 7-13: mean $\mathrm{N}_{2} \mathrm{O} /\left(\mathrm{N}_{2}+\mathrm{N}_{2} \mathrm{O}\right)$ of $0.27 \pm 0.02$ ).

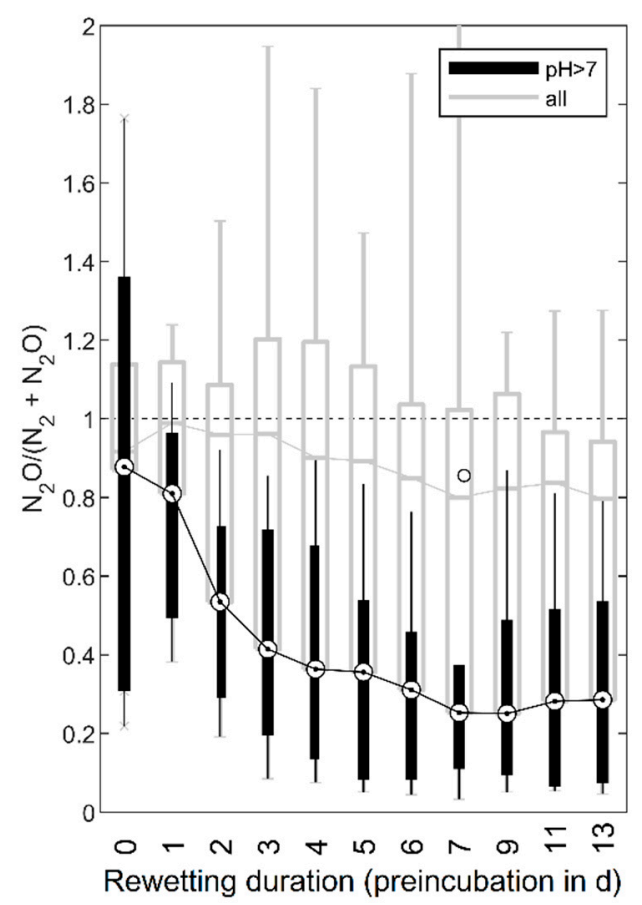

Figure 2. Boxplots of denitrification product ratios $\left(\mathrm{N}_{2} \mathrm{O} /\left(\mathrm{N}_{2} \mathrm{O}+\mathrm{N}_{2}\right)\right)$ after different periods of rewetting for the entire soil sample subset (grey) compared with the soils from $\mathrm{pH}$ class $>7$ (black). The boxplots show the inter-quartile-range (box $=25$ th to 75 th percentile with median (50th percentile)), 90th and 10th percentile (upper and lower whisker), and outliers (circle).

\subsection{Influence of the Soil Parameters $p H, N m i n$ and FC}

The results of the time series reveal that there is a significant influence of $\mathrm{pH}$ and $\mathrm{FC}$ on the denitrification product ratio $\mathrm{N}_{2} \mathrm{O} /\left(\mathrm{N}_{2}+\mathrm{N}_{2} \mathrm{O}\right)$ even when all rewetting periods were considered. We found significant differences between the $\mathrm{pH}$ class $>7$ and $<7$ and between the FC class I and III as well as between the FC class II and III. The Nmin-content of the soils had no significant influence on the denitrification product ratio (Table 2).

Table 2. Comparison of the denitrification product ratios $\left(\mathrm{N}_{2} \mathrm{O} /\left(\mathrm{N}_{2} \mathrm{O}+\mathrm{N}_{2}\right)\right)$ for the rewetting days 0 to 13 of all subdivided classes ( $\mathrm{pH}$ class $(\mathrm{n}=66)$, Nmin class $(\mathrm{n}=66)$, FC class $(\mathrm{n}=66))$. Method used: Mann-Whitney U-Test $(\mathrm{U})$. (significance levels $p>0.05(-)=$ not significant, $p \leq 0.01\left({ }^{* *}\right)=$ very significant, $p \leq 0.001(* *)=$ highly significant result).

\begin{tabular}{|c|c|c|}
\hline \multicolumn{2}{|c|}{ Class } & \multirow{2}{*}{$\begin{array}{c}\mathbf{N}_{\mathbf{2}} \mathbf{O} /\left(\mathbf{N}_{\mathbf{2}} \mathbf{O}+\mathbf{N}_{\mathbf{2}}\right) \text { Ratio } \\
\mathrm{U}=4123, p<2.2 \times 10^{-16}\left(^{* * *}\right)\end{array}$} \\
\hline $\mathrm{pH}$ & pH low/pH high & \\
\hline mineral nitrogen content & $\mathrm{N}_{\min }$ high $/ \mathrm{N}_{\min }$ low & $\mathrm{U}=2042, p<0.5374(-)$ \\
\hline & FC I/FC II & $\mathrm{U}=798, p<0.4648(-)$ \\
\hline \multirow[t]{2}{*}{ field capacity } & FC I/FC III & $\mathrm{U}=1208, p<0.009702^{(* *)}$ \\
\hline & FC II/FC III & $\left.\mathrm{U}=1583, p<0.008785^{(* *}\right)$ \\
\hline
\end{tabular}




\section{Discussion}

\subsection{Denitrification Product Ratio: $\mathrm{N}_{2} \mathrm{O} /\left(\mathrm{N}_{2} \mathrm{O}+\mathrm{N}_{2}\right)$}

The applied method to measure denitrification is based on the ability of acetylene $\left(\mathrm{C}_{2} \mathrm{H}_{2}\right)$ to inhibit the reduction of $\mathrm{N}_{2} \mathrm{O}$ to $\mathrm{N}_{2}$ [15]. However, higher denitrification rates do not necessarily lead to higher $\mathrm{N}_{2} \mathrm{O}$ emissions, since increased denitrification can also change the proportion of $\mathrm{N}_{2} \mathrm{O}$ between the two gaseous products $\mathrm{N}_{2} \mathrm{O}$ and $\mathrm{N}_{2}$ [52]. The ratio between $\mathrm{N}_{2} \mathrm{O}$ emissions in treatments without acetylene and $\mathrm{N}_{2} \mathrm{O}$ emissions in treatments with acetylene (DEA) is interpreted as the denitrification product ratio $\mathrm{N}_{2} \mathrm{O} /\left(\mathrm{N}_{2}+\mathrm{N}_{2} \mathrm{O}\right)$ respectively $\mathrm{DEA}_{\mathrm{N} 2 \mathrm{O}} / \mathrm{DEA}$ [53]. If this product ratio is used as a measure for the optimal rewetting period for denitrification, the lowest ratio must be considered, as it covers the potential $\mathrm{N}_{2}$ emissions from the ratio between $\mathrm{N}_{2} \mathrm{O}$ and $\left(\mathrm{N}_{2}+\mathrm{N}_{2} \mathrm{O}\right)$ : the lower the ratio, the greater the proportion of $\mathrm{N}_{2}$ in the denitrification product $\mathrm{N}_{2}+\mathrm{N}_{2} \mathrm{O}$. A ratio above 1 is theoretically impossible. However, ratios above one can be found if measurements are inaccurate or analytical replicates are averaged or measured denitrification values are very low, and thus the calculation shows artifacts. In this case, instead of calculating the ratio, it would be reasonable to describe $\mathrm{N}_{2}$ as the difference between $\mathrm{N}_{2} \mathrm{O}$ emissions with and without the acetylene treatment $[17,54,55]$. However, in our study, this case of very low values only occurred once (\#4). Since elevated $\mathrm{N}_{2} \mathrm{O}$ fluxes were observed in all other situations, it makes sense to include a scaling factor by calculation of the ratio [17].

Because $\mathrm{N}_{2} \mathrm{O}$ can be produced both in the autotrophic nitrification and the heterotrophic denitrification process [56], additional ratios above one can be found if the environment is not completely oxygen-free during incubation. The amount of $\mathrm{N}_{2} \mathrm{O}$ produced through nitrification increases with decreasing soil oxygen concentrations [57]. In addition to the $\mathrm{O}_{2}$ partial pressure in the gas phase, the availability of $\mathrm{O}_{2}$ in soil is controlled by moisture content [58,59]. Studies have shown an increased denitrification rate through restricted soil aeration linked with high soil water content (e.g., Hefting et al. (2004) [9]). For this reason, we pre-incubated the soil sample subset to $100 \%$ WFPS over different periods of duration to obtain anaerobic conditions and to favor $\mathrm{N}_{2} \mathrm{O}$ release through denitrification [59]. in addition to these, other processes such as nitrifier denitrification, heterotrophic nitrification (fungi and bacteria), and DNRA can also produce $\mathrm{N}_{2} \mathrm{O}$ [60]. Especially nitrifier denitrification could be an undetected contributor to measured $\mathrm{N}_{2} \mathrm{O}$ emissions, since Wrage et al., (2004) [21] showed that $\mathrm{C}_{2} \mathrm{H}_{2}$ inhibited $\mathrm{N}_{2} \mathrm{O}$ production by Nitrosomonas europaea but it did not affect the $\mathrm{N}_{2} \mathrm{O}$ production in Nitrosomonas briensis. Kool et al., (2010) [60] conjecture that lower $\mathrm{pH}$ might favor nitrifier denitrification, which could be the explanation of ratios above one. To verify the importance of this process dual-isotope measurements with ${ }^{15} \mathrm{~N}$ and ${ }^{18} \mathrm{O}$ should be done because only this could prove the presence of nitrifier denitrification in soils [60]. Following studies should examine the relationship between $\mathrm{N}_{2} \mathrm{O}$ and changing nitrate levels during incubation for better interpretation of the results.

\subsection{The Influence of Rewetting}

In addition to the described effect of missing $\mathrm{O}_{2}$ availability through saturation, rewetting causes enhanced organic matter mineralization $[61,62]$. Many studies have shown pulses of $\mathrm{N}_{2} \mathrm{O}$ emission following the rewetting of dried soils [10,42,63,64]. As expected, in both treatments we found an increase in $\mathrm{N}_{2} \mathrm{O}$ emission after rewetting with short time (1d) $\mathrm{N}_{2} \mathrm{O}$ emission peaks in the entire subset, but especially for group 4 (Figure 1). However, to establish a standardized procedure, we required a time series analysis to find the optimal duration of rewetting for measuring potential denitrification. To achieve this, we therefore searched for the lowest $(<1)$ and most stable denitrification product ratios.

Based on the results obtained showing that soils of both acetylene treatments in the $\mathrm{pH}$ class $<7$ have very similar $\mathrm{N}_{2} \mathrm{O}$ emission curve progressions (Figure 1), we assume that in this instance the complete denitrification process (up to $\mathrm{N}_{2}$ ) rarely takes place, resulting in high $\mathrm{N}_{2} \mathrm{O} /\left(\mathrm{N}_{2}+\mathrm{N}_{2} \mathrm{O}\right)$ ratios of around one. This means that for this group we were not able to analyze the effect of different rewetting durations on denitrification. Furthermore, we found that soils in the $\mathrm{pH}$ class $>7$ showed 
constant ratios, even if they occurred in different groups after different periods of rewetting (Figure 1). The analysis of those constant ratios showed that one should rewet at least seven days to obtain the most stable denitrification product ratios. These findings are in line with, e.g., Qin et al. (2013) [19] and D'Haene et al. (2003) [39]. In both studies air-dried soil samples were pre-incubated for seven days before conducting denitrification experiments, although fresh field samples are a prerequisite for the AIT.

In addition to the achieved goal of finding an optimal rewetting duration, this also allows assumptions to be made about the influence of potential flooding dynamics in the field. For example, the observed decrease in the $\mathrm{N}_{2} \mathrm{O} /\left(\mathrm{N}_{2} \mathrm{O}+\mathrm{N}_{2}\right)$ ratios for the class $\mathrm{pH}>7$ suggests that floodplain soils must be flooded for at least seven days after a dry period in order to achieve a maximum $\mathrm{N}_{2}$ emission through denitrification and to enable a more complete denitrification process. However, for the general activation of denitrifying bacteria, a short flood of one day would already be sufficient, as shown by the measured DEA peaks (see $\mathrm{N}_{2} \mathrm{O}$ emission with acetylene in Figure 1).

Furthermore, Ruser et al. (2006) [64] and Yanai et al. (2010) [63] described the stimulating effects of rewetting. Nevertheless, a general decrease in the activity of microorganisms through dried storage is also likely [41]. This was not the aim of this study, however, because AIT-derived SDP results (even with fresh soils) can only be poorly related to actual denitrification activity [12].

\subsection{Influence of the Soil Parameters $p H, N m i n$, and FC}

Despite the ambiguous relationship between $\mathrm{pH}$ and DEA $[65,66]$, it is generally accepted that lower soil $\mathrm{pH}$ results in higher denitrification product ratios [67]. We were able to prove that denitrification in acidic soils resulted in more $\mathrm{N}_{2} \mathrm{O}$, leading to increased $\mathrm{N}_{2} \mathrm{O} /\left(\mathrm{N}_{2}+\mathrm{N}_{2} \mathrm{O}\right)$ ratios when compared with neutral or slightly alkaline soils $[66,68,69]$. A synopsis of various studies across different soil types shows that there may be a negative exponential correlation between ratio and $\mathrm{pH}$ [70]. The control mechanisms behind this are not fully understood. However, the following can be considered: sensitive bacterial denitrification enzymes (Nos) [67], pH-based fungi dominance resulting in a lack of Nos, favored $\mathrm{N}_{2} \mathrm{O}$ production by nitrifiers in acidic soils, and enhanced abiotic transformations of $\mathrm{NO}_{3}$ [16].

Moreover, we assumed the proximal regulator $\mathrm{Nmin}$ (especially in the form of $\mathrm{NO}_{3}$ ) as one of the factors limiting denitrification, to be essential for the formation of a denitrifying bacterial community. Many studies found this positive relationship between the denitrification rate and $\mathrm{NO}_{3}$ concentrations (e.g., Zhong et al., 2010 [71]). However, this only applies up to a certain value: more than $50 \mu g \mathrm{NO}_{3}-\mathrm{N}$ per g DM may be harmful to denitrification activity [72]. Due to the suppression of Nos, higher $\mathrm{NO}_{3}$ concentration usually results in higher denitrification product ratios [73], because reducing $\mathrm{NO}_{3}$ is a priority in terms of energy compared to reducing $\mathrm{NO}_{2}$ [16]. We were not able to confirm this with our experiment as we did not find any significant differences between the high and low Nmin class in the $\mathrm{N}_{2} \mathrm{O} /\left(\mathrm{N}_{2} \mathrm{O}+\mathrm{N}_{2}\right)$ ratios. It is more likely to be a question of the nitrate availability during the reaction. Nmin as an influencing variable would only become apparent if it had previously affected the soil since $\mathrm{NO}_{3}$ was added in excess during the experiment. $\mathrm{N}$ was added at $0.4 \mathrm{mg} / \mathrm{g}$ DM while the original Nmin soil content was between 0.002 and $0.067 \mathrm{mg} / \mathrm{g} \mathrm{DM}$, resulting in more or less equal $\mathrm{N}$ content in all samples and thus an overlay of the effect.

It is also known that denitrification increases with increasing fineness of the soil texture [39]. Therefore, FC, which depends on grain size distribution, soil structure, and soil organic matter content, was used as the third parameter for selection. Soils with a finer texture and thus a higher FC have a greater and longer water storage capacity, which in turn influences nutrient cycling within soil microsites [74]. Changes found with increased WFPS in denitrification product ratios also depend on the ability of the denitrifiers [75]. It can therefore be assumed that these kinds of soils are prone to high denitrification rates compared to coarser substrates. We were also able to partially observe this relationship in our experiment. We found significant differences between the $\mathrm{N}_{2} \mathrm{O} /\left(\mathrm{N}_{2}+\mathrm{N}_{2} \mathrm{O}\right)$ ratio of soils with a very high FC (FC class III) and the other two classes (FC class I and II). It should be noted, however, that the well-known relationship of increasing denitrification rates with increasing water content $[76,77]$ is not fully represented here because all soils were rewetted to $100 \%$ WFPS. 
Nevertheless, we can still confirm the findings of D'Haene et al. (2003) [39], namely that despite the same water content while rewetting, the denitrification potential is still strongly dependent on the soil texture.

In this context carbon availability, temperature, and the availability of trace metals, to name but a few, also affect denitrification. In short, we can confirm the known influences of the known parameters on the SDP. The aim of this study, however, was not to identify factors that influence the SDP. Known factors influencing the SDP were used to select a broad and representative set of soil samples despite the diversity of soils in order to determine a standard rewetting period that could be applied to the overall data set in the future. Although this was achieved, the limitations imposed by the relationships that were investigated between soil properties and distortions of the method must be taken into account: Essentially, the applicability of the AIT is given in soils with high or moderately nutrient content, since bias is low there [19]. Furthermore, high silt, clay, and low sand contents reduce these errors [19]. In our total data set soils will consist mainly of clays, silts, and loams, and nutrients are added before the four-hour incubation, relatively small amounts of distortion can be expected. Additionally, they are also more likely to occur in the sense of underestimation, as studies comparing the AIT with $\mathrm{N}_{2}$ :Ar ratio methods with membrane inlet mass spectrometry (MIMS) and direct $\mathrm{N}_{2}$ measurements have shown $[18,26]$. To achieve better reliability, AIT's SDPs, whether from fresh or rewetted samples, should undergo the application of a correction coefficient derived from other mentioned methods $[18,26]$.

\section{Conclusions}

When determining the denitrification potential of air-dried soil samples using AIT, we can make the following recommendations. In order to assess nitrate reduction by denitrification in general, it is sufficient to consider the $\mathrm{N}_{2} \mathrm{O}$ emissions alone. For this purpose, we recommend a rewetting time of one day or a further time series analysis over 24 hours after rewetting. For the latter, as our results showed a high microbial activity in the early phase of rewetting, a higher resolution of the data is required for accurate statements.

However, this study aimed in finding an optimal time period for the rewetting of air-dried soils, which ideally leads to complete denitrification in laboratory experiments. Thus, the largest possible proportion of $\mathrm{N}_{2}$ was of main interest here and we can recommend at least seven days of rewetting as the lowest stable calculated denitrification product ratios occurred after this period. This also means that active soils with high $\mathrm{N}_{2} \mathrm{O}$ emissions would be completely ignored in terms of their denitrification potential, even though they can contribute to nitrate reduction, even if it is only up to $\mathrm{N}_{2} \mathrm{O}$. This should be taken into account when using the ratio of $\mathrm{N}_{2} \mathrm{O}$ emissions with and without acetylene as a measure of the denitrification potential, especially for soils with low $\mathrm{pH}$ values.

The influence of the previous drying could not be determined and should be investigated in further experiments. However, even with soil samples that are fresh from the field, it is only the denitrification potential and not the actual denitrification rates that can be measured using this method.

Differences due to soil parameters such as $\mathrm{pH}$ and $\mathrm{FC}$ were also clearly visible in the results, and therefore this method is very promising for the comparison concerning denitrification of soils and ecosystems and for use in the next step to studying all 113 soil samples. When applying the method, in the context of $\mathrm{N}$-retention in floodplains, it remains to be noted that other nitrate-removing processes, such as DNRA, are not quantified. The proportion of these processes can be very high under certain circumstances [5]. Whether or not these are given for our study is difficult to predict, as freshwater ecosystem DNRA hotspots reported so far described sediments of riparian zones [5].

Author Contributions: Conceptualization, U.S.K. and C.S.-Z.; formal analysis, U.S.K., C.H., and C.S.-Z.; investigation, U.S.K. and C.S.-Z.; methodology, U.S.K. and C.S.-Z.; project administration, M.S.; resources, E.F., T.H., H.R., and M.S.; supervision, C.S.-Z.; writing-original draft, U.S.K. and C.S.-Z.; writing一review and editing, E.F., T.H., H.R., M.S., and C.S.-Z. All authors have read and agreed to the published version of the manuscript. 
Funding: This research received no external funding.

Acknowledgments: This study was part of the AZOTE project "Determining potential nutrient retention rates as an ecosystem service in riparian zones". The authors are much indebted to Sarah Gwillym-Margianto for her assistance in proofreading. This study was supported by the German Federal Institute of Hydrology, Koblenz. Many thanks to the farmers, land owners, and nature conservation authorities for their helpful cooperation in taking the samples in the field. Thanks to Peter Horchler (Koblenz) for his support and discussions in the project and to the lab personnel in Falkenberg and Lunz for their assistance and help in the experiments.

Conflicts of Interest: The authors declare that they have no known competing financial interests or personal relationships that could have appeared to influence the work reported in this paper.

\section{References}

1. Tockner, K.; Stanford, J.A. Riverine Flood Plains: Present State and Future Trends. Environ. Conserv. 2002, 29, 308-330. [CrossRef]

2. Hansson, L.A.; Brönmark, C.; Nilsson, P.A.; Åbjörnsson, K. Conflicting Demands on Wetland Ecosystem Services: Nutrient Retention, Biodiversity or Both? Freshw. Biol. 2005, 50, 705-714. [CrossRef]

3. Jordan, S.J.; Stoffer, J.; Nestlerode, J.A. Wetlands as Sinks for Reactive Nitrogen at Continental and Global Scales: A Meta-Analysis. Ecosystems 2011, 14, 144-155. [CrossRef]

4. Zedler, J.B. Wetlands at Your Service: Reducing Impacts of Agriculture at the Watershed Scale. Front. Ecol. Environ. 2003, 1, 65-72. [CrossRef]

5. Wang, S.; Pi, Y.; Song, Y.; Jiang, Y.; Zhou, L.; Liu, W.; Zhu, G. Hotspot of Dissimilatory Nitrate Reduction to Ammonium (DNRA) Process in Freshwater Sediments of Riparian Zones. Water Res. 2020, 173, 115539. [CrossRef] [PubMed]

6. Kuypers, M.M.M.; Marchant, H.K.; Kartal, B. The Microbial Nitrogen-Cycling Network. Nat. Rev. Microbiol. 2018, 16, 263-276. [CrossRef]

7. Decleyre, H.; Heylen, K.; Van Colen, C.; Willems, A. Dissimilatory Nitrogen Reduction in Intertidal Sediments of a Temperate Estuary: Small Scale Heterogeneity and Novel Nitrate-to-Ammonium Reducers. Front. Microbiol. 2015, 6, 1124. [CrossRef]

8. Burgin, A.J.; Hamilton, S.K. Have We Overemphasized the Role of Denitrification in Aquatic Ecosystems? A Review of Nitrate Removal Pathways. Front. Ecol. Environ. 2007, 5, 89-96. [CrossRef]

9. Hefting, M.; Clément, J.C.; Dowrick, D.; Cosandey, A.C.; Bernal, S.; Cimpian, C.; Tatur, A.; Burt, T.P.; Pinay, G. Water Table Elevation Controls on Soil Nitrogen Cycling in Riparian Wetlands along a European Climatic Gradient. Biogeochemistry 2004, 67, 113-134. [CrossRef]

10. Guo, X.; Drury, C.F.; Yang, X.; Reynolds, W.D.; Fan, R. The Extent of Soil Drying and Rewetting Affects Nitrous Oxide Emissions, Denitrification, and Nitrogen Mineralization. Soil Sci. Soc. Am. J. 2014, 78, $194-204$. [CrossRef]

11. Pinay, G.; Gumiero, B.; Tabacchi, E.; Gimenez, O.; Tabacchi-Planty, A.M.; Hefting, M.M.; Burt, T.P.; Black, V.A.; Nilsson, C.; Iordache, V.; et al. Patterns of Denitrification Rates in European Alluvial Soils under Various Hydrological Regimes. Freshw. Biol. 2007, 52, 252-266. [CrossRef]

12. Groffman, P.M.; Holland, E.A.; Myrold, D.D.; Robertson, G.P.; Zou, X. Denitrification. In Standard Soil methods for Long-Term Ecological Research; Robertson, G.P., Coleman, D.C., Bledsoe, C.S., Sollins, P., Eds.; Oxford University Press: New York, NY, USA, 1999; pp. 272-288.

13. Stevens, R.J.; Laughlin, R.J.; Atkins, G.J.; Prosser, S.J. Automated Determination of Nitrogen-15-Labeled Dinitrogen and Nitrous Oxide by Mass Spectrometry. Soil Sci. Soc. Am. J. 1993, 57, 981-988. [CrossRef]

14. Butterbach-Bahl, K.; Willibald, G.; Papen, H. Soil Core Method for Direct Simultaneous Determination of $\mathrm{N}_{2}$ and $\mathrm{N}_{2} \mathrm{O}$ Emissions from Forest Soils. Plant Soil 2002, 240, 105-116. [CrossRef]

15. Groffman, P.M.; Altabet, M.A.; Böhlke, J.K.; Butterbach-Bahl, K.; David, M.B.; Firestone, M.K.; Giblin, A.E.; Kana, T.M.; Nielsen, L.P.; Voytek, M.A. Methods for Measuring Denitrification: Diverse Approaches to a Difficult Problem. Ecol. Appl. 2006, 16, 2091-2122. [CrossRef]

16. Saggar, S.; Jha, N.; Deslippe, J.; Bolan, N.S.; Luo, J.; Giltrap, D.L.; Kim, D.; Zaman, M.; Tillman, R.W. Denitrification and $\mathrm{N}_{2} \mathrm{O}: \mathrm{N}_{2}$ Production in Temperate Grasslands: Processes, Measurements, Modelling and Mitigating Negative Impacts. Sci. Total Environ. 2013, 465, 173-195. [CrossRef] [PubMed]

17. Felber, R.; Conen, F.; Flechard, C.R.; Neftel, A. Theoretical and Practical Limitations of the Acetylene Inhibition Technique to Determine Total Denitrification Losses. Biogeosciences 2012, 9, 4125-4138. [CrossRef] 
18. Qin, S.; Hu, C.; Oenema, O. Quantifying the Underestimation of Soil Denitrification Potential as Determined by the Acetylene Inhibition Method. Soil Biol. Biochem. 2012, 47, 14-17. [CrossRef]

19. Qin, S.; Yuan, H.; Dong, W.; Hu, C.; Oenema, O.; Zhang, Y. Relationship between Soil Properties and the Bias of $\mathrm{N}_{2} \mathrm{O}$ Reduction by Acetylene Inhibition Technique for Analyzing Soil Denitrification Potential. Soil Biol. Biochem. 2013, 66, 182-187. [CrossRef]

20. Yuan, H.; Zhang, Z.; Qin, S.; Zhou, S.; Hu, C.; Clough, T.; Wrage-Mönnig, N.; Luo, J.; Conrad, R. Effects of Nitrate and Water Content on Acetylene Inhibition Technique Bias When Analysing Soil Denitrification Rates under an Aerobic Atmosphere. Geoderma 2019, 334, 33-36. [CrossRef]

21. Dalsgaard, T.; Bak, F. Effect of Acetylene on Nitrous Oxide Reduction and Sulfide Oxidation in Batch and Gradient Cultures of Thiobacillus Denitrificans. Appl. Environ. Microbiol. 1992, 58, 1601-1608. [CrossRef]

22. Yu, K.; Seo, D.C.; Delaune, R.D. Incomplete Acetylene Inhibition of Nitrous Oxide Reduction in Potential Denitrification Assay as Revealed by Using ${ }^{15} \mathrm{~N}-$ Nitrate Tracer. Commun. Soil Sci. Plant Anal. 2010, 41, 2201-2210. [CrossRef]

23. Seitzinger, S.P.; Nielsen, L.P.; Caffrey, J.; Christensen, P.B. Denitrification Measurements in Aquatic Sediments: A Comparison of Three Methods. Biogeochemistry 1993, 23, 147-167. [CrossRef]

24. Wrage, N.; Velthof, G.L.; Oenema, O.; Laanbroek, H.J. Acetylene and Oxygen as Inhibitors of Nitrous Oxide Production in Nitrosomonas Europaea and Nitrosospira Briensis: A Cautionary Tale. FEMS Microbiol. Ecol. 2004, 47, 13-18. [CrossRef]

25. Watts, S.H.; Seitzinger, S.P. Denitrification Rates in Organic and Mineral Soils from Riparian Sites: A Comparison of $\mathrm{N}_{2}$ Flux and Acetylene Inhibition Methods. Soil Biol. Biochem. 2000, 32, 1383-1392. [CrossRef]

26. She, D.; Sun, X.; Xia, Y. Combining $\mathrm{N}_{2}$ :Ar and Bayesian Methods to Quantify Underestimation and Uncertainty of Sediment Denitrification Determined by the Acetylene Inhibition Method. Water Air Soil Pollut. 2019, 230, 52. [CrossRef]

27. Liu, R.; Hayden, H.L.; Hu, H.; He, J.; Suter, H.; Chen, D. Effects of the Nitrification Inhibitor Acetylene on Nitrous Oxide Emissions and Ammonia-Oxidizing Microorganisms of Different Agricultural Soils under Laboratory Incubation Conditions. Appl. Soil Ecol. 2017, 119, 80-90. [CrossRef]

28. Jin, Y.; Jury, W.A. Characterizing the Dependence of Gas Diffusion Coefficient on Soil Properties. Soil Sci. Soc. Am. J. 1996, 60, 66-71. [CrossRef]

29. Culbertson, C.W.; Zehnder, A.J.B.; Oremland, R.S. Anaerobic Oxidation of Acetylene by Estuarine Sediments and Enrichment Cultures. Appl. Environ. Microbiol. 1981, 41, 396-403. [CrossRef]

30. Topp, E.; Germon, J.C. Acetylene Metabolism and Stimulation of Denitrification in an Agricultural Soil. Appl. Environ. Microbiol. 1986, 52, 802-806. [CrossRef]

31. Meng, L.; Ding, W.; Cai, Z. Long-Term Application of Organic Manure and Nitrogen Fertilizer on $\mathrm{N}_{2} \mathrm{O}$ Emissions, Soil Quality and Crop Production in a Sandy Loam Soil. Soil Biol. Biochem. 2005, 37, 2037-2045. [CrossRef]

32. Russell, M.; Fulford, R.; Murphy, K.; Lane, C.; Harvey, J.; Dantin, D.; Alvarez, F.; Nestlerode, J.; Teague, A.; Harwell, M.; et al. Relative Importance of Landscape Versus Local Wetland Characteristics for Estimating Wetland Denitrification Potential. Wetlands 2019, 39, 127-137. [CrossRef]

33. Smith, M.S.; Tiedje, J.M. Phases of Denitrification Following Oxygen Depletion in Soil. Soil Biol. Biochem. 1979, 11, 261-267. [CrossRef]

34. Genthner, F.J.; Marcovich, D.T.; Lehrter, J.C. Estimating Rates of Denitrification Enzyme Activity in Wetland Soils with Direct Simultaneous Quantification of Nitrogen and Nitrous Oxide by Membrane Inlet Mass Spectrometry. J. Microb. Biochem. Technol. 2013, 5, 95-101. [CrossRef]

35. Smith, M.S.; Parsons, L.L. Persistence of Denitrifying Enzyme Activity in Dried Soils. Appl. Environ. Microbiol. 1985, 49, 316-320. [CrossRef]

36. Pinay, G.; Black, V.J.; Planty-Tabacchi, A.M.; Gumiero, B.; Décamps, H. Geomorphic Control of Denitrification in Large River Floodplain Soils. Biogeochemistry 2000, 50, 163-182. [CrossRef]

37. Waters, E.R.; Morse, J.L.; Bettez, N.D.; Groffman, P.M. Differential Carbon and Nitrogen Controls of Denitrification in Riparian Zones and Streams along an Urban to Exurban Gradient. J. Environ. Qual. 2014, 43, 955-963. [CrossRef]

38. Xiong, Z.; Li, S.; Yao, L.; Liu, G.; Zhang, Q.; Liu, W. Topography and Land Use Effects on Spatial Variability of Soil Denitrification and Related Soil Properties in Riparian Wetlands. Ecol. Eng. 2015, 83, 437-443. [CrossRef] 
39. D’Haene, K.; Moreels, E.; De Neve, S.; Daguilar, B.C.; Boeckx, P.; Hofman, G.; Van Cleemput, O. Soil Properties Influencing the Denitrification Potential of Flemish Agricultural Soils. Biol. Fertil. Soils 2003, 38, 358-366. [CrossRef]

40. Mukumbuta, I.; Uchida, Y.; Hatano, R. Evaluating the Effect of Liming on $\mathrm{N}_{2} \mathrm{O}$ Fluxes from Denitrification in an Andosol Using the Acetylene Inhibition and ${ }^{15} \mathrm{~N}$ Isotope Tracer Methods. Biol. Fertil. Soils 2018, 54, 71-81. [CrossRef]

41. Fierer, N.; Schimel, J.P.; Holden, P.A. Influence of Drying-Rewetting Frequency on Soil Bacterial Community Structure. Microb. Ecol. 2003, 45, 63-71. [CrossRef]

42. Leitner, S.; Homyak, P.M.; Blankinship, J.C.; Eberwein, J.; Jenerette, G.D.; Zechmeister-Boltenstern, S.; Schimel, J.P. Linking NO and $\mathrm{N}_{2} \mathrm{O}$ Emission Pulses with the Mobilization of Mineral and Organic N upon Rewetting Dry Soils. Soil Biol. Biochem. 2017, 115, 461-466. [CrossRef]

43. Alldred, M.; Baines, S.B. Effects of Wetland Plants on Denitrification Rates: A Meta-Analysis. Ecol. Appl. 2016, 26, 676-685. [CrossRef] [PubMed]

44. DIN ISO 10390:2005-12. Bodenbeschaffenheit-Bestimmung des pH-Wertes; Beuth: Berlin, Germany, 2005.

45. VDLUFA. A 6.1.4.1 Bestimmung von Mineralischem Stickstoff (Nitrat und Ammonium) in Bodenprofilen (Nmin-Labormethode). In Das VDLUFA Methodenbuch—Band I Die Untersuchung von Böden; LUFA: Speyer, Germany, 1991; p. 1655.

46. DIN ISO 11277:2002-08. Bodenbeschaffenheit-Bestimmung der Partikelgrößenverteilung in Mineralböden-Verfah ren Mittels Siebung und Sedimentation. 2002. Available online: https://www.beuth.de/en/standard/din-iso11277/53934894 (accessed on 15 July 2020). [CrossRef]

47. Ad-hoc-AG Boden. Bodenkundliche Kartieranleitung. KA5. 2005. Available online: https://www.schweizerbart. de/publications/detail/isbn/9783510959204 (accessed on 15 July 2020).

48. DIN 18126:1996-11. Baugrund, Untersuchung von Bodenproben-Bestimmung der Dichte nichtbindiger Böden bei Lockerster und Dichtester Lagerung. 1996. Available online: https://www.beuth.de/en/standard/din-18126/ 2863234 (accessed on 15 July 2020). [CrossRef]

49. DIN EN 15936:2012-11. Schlamm, Behandelter Bioabfall, Boden und Abfall-Bestimmung des Gesamten Organischen Kohlenstoffs (TOC) Mittels Trockener Verbrennung. 2012. Available online: https://www.beuth. de/en/standard/din-en-15936/149052152 (accessed on 15 July 2020). [CrossRef]

50. Luo, J.; Tillman, R.W.; White, R.E.; Ball, P.R. Variation in Denitrification Activity with Soil Depth under Pasture. Soil Biol. Biochem. 1998, 30, 897-903. [CrossRef]

51. Yoshinari, T.; Hynes, R.; Knowles, R. Acetylene Inhibition of Nitrous Oxide Reduction and Measurement of Denitrification and Nitrogen Fixation in Soil. Soil Biol. Biochem. 1977, 9, 177-183. [CrossRef]

52. Senbayram, M.; Chen, R.; Budai, A.; Bakken, L.; Dittert, K. $\mathrm{N}_{2} \mathrm{O}$ Emission and the $\mathrm{N}_{2} \mathrm{O} /\left(\mathrm{N}_{2} \mathrm{O}+\mathrm{N}_{2}\right)$ Product Ratio of Denitrification as Controlled by Available Carbon Substrates and Nitrate Concentrations. Agric. Ecosyst. Environ. 2012, 147, 4-12. [CrossRef]

53. Welti, N.; Bondar-Kunze, E.; Singer, G.; Tritthart, M.; Zechmeister-Boltenstern, S.; Hein, T.; Pinay, G. Large-scale Controls on Potential Respiration and Denitrification in Riverine Floodplains. Ecol. Eng. 2012, 42, 73-84. [CrossRef]

54. Menéndez, S.; López-Bellido, R.J.; Benítez-Vega, J.; González-Murua, C.; López-Bellido, L.; Estavillo, J.M. Long-term Effect of Tillage, Crop Rotation and N Fertilization to Wheat on Gaseous Emissions under Rainfed Mediterranean Conditions. Eur. J. Agronomy 2008, 28, 559-569. [CrossRef]

55. Estavillo, J.M.; Merino, P.; Pinto, M.; Yamulki, S.; Gebauer, G.; Sapek, A.; Corré, W. Short Term Effect of Ploughing a Permanent Pasture on $\mathrm{N}_{2} \mathrm{O}$ Production from Nitrification and Denitrification. Plant Soil 2002, 239, 253-265. [CrossRef]

56. Firestone, M.K.; Davidson, E.A. Microbiological Basis of $\mathrm{NO}$ and $\mathrm{N}_{2} \mathrm{O}$ Production and Consumption in Soil. In Exchange of Trace Gases between Terrestrial Ecosystems and the Atmosphere; Schimel, D.S., Andreae, M.O., Eds.; John Wiley \& Sons: Berlin, Germany, 1989; pp. 7-21.

57. Bremner, J.M.; Blackmer, A.M. Effects of Acetylene and Soil Water Content on Emission of Nitrous Oxide from Soils. Nature 1979, 280, 380-381. [CrossRef]

58. Drury, C.F.; Findlay, W.I.; McKenney, D.J. Nitric Oxide and Nitrous Oxide Production from Soil: Water and Oxygen Effects. Soil Sci. Soc. Am. J. 1992, 56, 766-770. [CrossRef]

59. Bollmann, A.; Conrad, R. Influence of $\mathrm{O}_{2}$ Availability on $\mathrm{NO}$ and $\mathrm{N}_{2} \mathrm{O}$ Release by Nitrification and Denitrification in Soils. Glob. Chang. Biol. 1998, 4, 387-396. [CrossRef] 
60. Kool, D.M.; Wrage, N.; Zechmeister-Boltenstern, S.; Pfeffer, M.; Brus, D.; Oenema, O.; Van Groenigen, J.W. Nitrifier Denitrification Can Be a Source of $\mathrm{N}_{2} \mathrm{O}$ from Soil: A Revised Approach to the Dual-Isotope Labelling Method. Eur. J. Soil Sci. 2010, 61, 759-772. [CrossRef]

61. Fierer, N.; Schimel, J.P. Effects of Drying-Rewetting Frequency on Soil Carbon and Nitrogen Transformations. Soil Biol. Biochem. 2002, 34, 777-787. [CrossRef]

62. Muhr, J.; Goldberg, S.D.; Borken, W.; Gebauer, G. Repeated Drying-Rewetting Cycles and Their Effects on the Emission of $\mathrm{CO}_{2}, \mathrm{~N}_{2} \mathrm{O}, \mathrm{NO}$, and $\mathrm{CH}_{4}$ in a Forest Soil. J. Plant Nutr. Soil Sci. 2008, 171, 719-728. [CrossRef]

63. Yanai, Y.; Toyota, K.; Okazaki, M. Effects of Charcoal Addition on $\mathrm{N}_{2} \mathrm{O}$ Emissions from Soil Resulting from Rewetting Air-Dried Soil in Short-Term Laboratory Experiments. Soil Sci. Plant Nutr. 2007, 53, 181-188. [CrossRef]

64. Ruser, R.; Flessa, H.; Russow, R.; Schmidt, G.; Buegger, F.; Munch, J.C. Emission of $\mathrm{N}_{2} \mathrm{O}, \mathrm{N}_{2}$ and $\mathrm{CO}_{2}$ from Soil Fertilized with Nitrate: Effect of Compaction, Soil Moisture and Rewetting. Soil Biol. Biochem. 2006, 38, 263-274. [CrossRef]

65. Šimek, M.; Jíšová, L.; Hopkins, D.W. What Is the So-Called Optimum pH for Denitrification in Soil? Soil Biol. Biochem. 2002, 34, 1227-1234. [CrossRef]

66. Šimek, M.; Cooper, J.E. The Influence of Soil pH on Denitrification: Progress towards the Understanding of This Interaction over the Last 50 Years. Eur. J. Soil Sci. 2002, 53, 345-354. [CrossRef]

67. Liu, B.; Mørkved, P.T.; Frostegård, Å.; Bakken, L.R. Denitrification Gene Pools, Transcription and Kinetics of $\mathrm{NO}, \mathrm{N}_{2} \mathrm{O}$ and $\mathrm{N}_{2}$ Production as Affected by Soil pH Article. FEMS Microbiol. Ecol. 2010, 72, 407-417. [CrossRef]

68. Zaman, M.; Nguyen, M.L.; Saggar, S. $\mathrm{N}_{2} \mathrm{O}$ and $\mathrm{N}_{2}$ Emissions from Pasture and Wetland Soils with and without Amendments of Nitrate, Lime and Zeolite under Laboratory Condition. Aust. J. Soil Res. 2008, 46, 526-534. [CrossRef]

69. Čuhel, J.; Šimek, M.; Laughlin, R.J.; Bru, D.; Chèneby, D.; Watson, C.J.; Philippot, L. Insights into the Effect of Soil $\mathrm{pH}$ on $\mathrm{N}_{2} \mathrm{O}$ and $\mathrm{N}_{2}$ Emissions and Denitrifier Community Size and Activity. Appl. Environ. Microbiol. 2010, 76, 1870-1878. [CrossRef] [PubMed]

70. Rochester, I.J. Estimating Nitrous Oxide Emissions from Flood-Irrigated Alkaline Grey Clays. Aust. J. Soil Res. 2003, 41, 197-206. [CrossRef]

71. Zhong, J.; Fan, C.; Zhang, L.; Hall, E.; Ding, S.; Li, B.; Liu, G. Significance of Dredging on Sediment Denitrification in Meiliang Bay, China: A Year Long Simulation Study. J. Environ. Sci. 2010, 22, 68-75. [CrossRef]

72. Luo, J.; White, R.E.; Ball, P.R.; Tillmann, R.W. Measuring Denitrification Activity in Soils under Pasture: Optimizing Conditions for the Short-Term Denitrification Enzyme Assay and Effects of Soil Storage on Denitrification Activity. So Biol. Biochem. 1996, 28, 409-417. [CrossRef]

73. Zaman, M.; Nguyen, M.L.; Matheson, F.; Blennerhassett, J.D.; Quin, B.F. Can Soil Amendments (Zeolite or Lime) Shift the Balance between Nitrous Oxide and Dinitrogen Emissions from Pasture and Wetland Soils Receiving Urine or Urea-N? Aust. J. Soil Res. 2007, 45, 543-553. [CrossRef]

74. Castellano, M.J.; Lewis, D.B.; Kaye, J.P. Response of Soil Nitrogen Retention to the Interactive Effects of Soil Texture, Hydrology, and Organic Matter. J. Geophys. Res. Biogeosci. 2013, 118, 280-290. [CrossRef]

75. Morley, N.; Baggs, E.M.; Dörsch, P.; Bakken, L. Production of NO, $\mathrm{N}_{2} \mathrm{O}$ and $\mathrm{N}_{2}$ by Extracted Soil Bacteria, Regulation by $\mathrm{NO}_{2}{ }^{-}$and $\mathrm{O}_{2}$ Concentrations. FEMS Microbiol. Ecol. 2008, 65, 102-112. [CrossRef]

76. Abbasi, M.K.; Adams, W.A. Gaseous N Emission during Simultaneous Nitrification-Denitrification Associated with Mineral N Fertilization to a Grassland Soil under Field Conditions. Soil Biol. Biochem. 2000, 32, 1251-1259. [CrossRef]

77. Hénault, C.; Germon, J.C. NEMIS, a Predictive Model of Denitrification on the Field Scale. Eur. J. Soil Sci. 2000, 51, 257-270. [CrossRef]

Publisher's Note: MDPI stays neutral with regard to jurisdictional claims in published maps and institutional affiliations.

(C) 2020 by the authors. Licensee MDPI, Basel, Switzerland. This article is an open access article distributed under the terms and conditions of the Creative Commons Attribution (CC BY) license (http://creativecommons.org/licenses/by/4.0/). 